Undas Vol 12. , Nomor 2, Desember 2016 : 11--24

\title{
IMPLIKATUR PERCAKAPAN DALAM TRANSAKSI JUAL BELI DI PASAR HEWAN WAGE TULAKAN
}

\author{
Conversational Implicature Sale Transactions in the Market in Animal Wage Tulakan
}

\section{Hestiyana}

Balai Bahasa Kalimantan Selatan

Jalan Jenderal Ahmad Yani Km 32,2, Loktabat, Banjarbaru 70712 Kalimantan Selatan

Telepon (0511) 4772641, Pos-el: hestiyana21@gmail.com

\begin{abstract}
Abstrak: Penelitian ini bertujuan untuk mendeskripsikan implikatur percakapan yang digunakan oleh penjual dan pembeli dalam transaksi jual beli di Pasar Hewan Wage Tulakan. Penelitian ini menggunakan metode deskriptif dengan pendekatan kualitatif. Sumber data dalam penelitian ini adalah bahasa lisan yang dituturkan oleh penjual dan pembeli yang sedang melakukan transaksi jual beli di Pasar Hewan Wage Tulakan. Dalam penyediaan data digunakan metode simak, baik simak libat cakap atau simak bebas libat cakap dan teknik catat. Pada tahap analisis data, tuturan antara penjual dan pembeli diklasifikasikan berdasarkan penggunaan implikatur percakapan. Setelah dilakukan penelitian secara mendalam, pada saat transaksi jual beli berlangsung antara penjual dan pembeli sering menggunakan implikatur percakapan. Bentuk implikatur percakapan yang digunakan, yaitu: implikatur percakapan dalam kalimat perintah, implikatur percakapan dalam kalimat berita, dan implikatur percakapan dalam kalimat tanya.
\end{abstract}

Kata kunci: Pragmatik, implikatur percakapan, kalimat perintah, kalimat berita, kalimat tanya

Abstract: This study aimed to describe conversational implicatures used by the seller and the buyer in the sale and purchase transactions in the Market Wage Animal Tulakan. This research uses descriptive method with qualitative approach. Sources of data in this study is the spoken language spoken by sellers and buyers who are buying or selling in the Market Wage Animal Tulakan. In the method of providing data used refer to, either proficient or refer see involved capably and techniques involved free record. At this stage of data analysis, speech between the seller and the buyer are classified based on the use of conversational implicature. After in-depth research, at the time of sale and purchase transactions take place between sellers and buyers often use conversational implicature. Forms of conversational implicatures used: conversational implicatures order to form a sentence, the sentence shaped conversational implicature news, and conversational implicatures shaped interrogative sentence.

Key words: Pragmatics, conversational implicature, imperative sentences, sentence news, interrogative sentence

\section{PENDAHULUAN}

Manusia merupakan makhluk sosial, yaitu makhluk yang dalam kehidupannya selalu hidup bermasyarakat. Dalam kehidupan bermasyarakat ini tentunya menggunakan bahasa sebagai alat komunikasi. Bahasa mengandung ide, gagasan, pikiran, serta perasaan si 
penutur. Agar penutur dapat mengemukakan ide dan perasaannya tersebut, digunakanlah bahasa untuk mengemukakannya. Dengan kata lain, bahasa menjadi alat penyampai pesan dari penutur kepada mitra tutur, baik secara lisan maupun tertulis.

Di dalam berkomunikasi, penutur dan mitra tutur harus memiliki kesamaan latar belakang pengetahuan tentang sesuatu yang dipertuturkan. Hal ini seperti yang dikemukakan Pranowo (2012: 12) bahwa komunikasi akan berhasil apabila didukung oleh beberapa faktor, seperti : (1) ada kesepahaman topik yang dibicarakan antara penutur dengan mitra tutur; (2) ada kesepemahaman bahasa yang digunakan oleh penutur kepada mitra tutur; (3) mitra tutur tertarik dengan pesan yang disampaikan oleh penutur; (4) penutur dan mitra tutur sama-sama dalam konteks dan situasi yang sama; (5) pranggapan penutur terhadap mitra tutur benar; dan (6) penutur mahir memanfaatkan daya bahasa yang menjadikan komunikasi lebih efektif.

Dengan demikian, bahasa yang digunakan sebagai alat untuk berinteraksi diharapkan antara penutur dengan mitra tutur dapat saling memahami maksud, ide, ataupun gagasan-gagasan yang dipertuturkan tersebut. Alwasilah (2010: 45) mengemukakan bahwa nurani terdalam yang ada pada manusia adalah keinginan dirinya diakui dan dimengerti oleh anggota masyarakat lain lewat komunikasi dengan bahasa masyarakat itu. Kemudian, Muslich (2010: 112) menambahkan bahwa bahasa adalah salah satu dari lembaga sosial kemanusiaan. Hal ini menunjukkan bahwa pentingnya sebuah bahasa di dalam berkomunikasi antar penutur dalam membentuk sebuah komunikasi sosial.

Berbahasa adalah aktivitas sosial. Seperti halnya aktivitas sosial yang lain, kegiatan berbahasa baru terwujud apabila manusia terlibat di dalamnya. Di dalam berbicara, penutur dan lawan tutur sama-sama menyadari bahwa kaidah-kaidah yang mengatur tindakannya, penggunaan bahasa, dan interpretasi-interpretasinya terhadap tindakan dan ucapan lawan tutur. Setiap peserta tutur bertanggung jawab terhadap tindakan dan penyimpangan kaidah kebahasaan dalam interaksi lingual itu (Wijana, 1996: 45). Dengan kata lain, agar penutur dan mitra tutur dapat saling berinteraksi maka keduanya harus saling memahami sesuatu yang dipertuturkan tersebut. Misalnya, komunikasi yang terjadi antara penjual dan pembeli dalam melakukan transaksi jual beli di pasar.

Pasar merupakan tempat penjual dan pembeli bertemu, barang dan jasa tersedia untuk dijual dan akan terjadi pemindahan hak milik (Swastha, 1996: 50). Tawar menawar sebagai bentuk interaksi di dalamnya tentu melibatkan bahasa. Dengan demikian, tawar menawar termasuk salah satu peristiwa tutur (speech event). Sebagai salah satu peristiwa tutur, wujud pemakaian bahasa dipengaruhi oleh berbagai faktor, seperti situasi dan peristiwa, peserta tutur, tujuan berbicara, normanorma interaksi dan sebagainya (Suharsono dalam Jahdiah, 2013: 27).

Dalam hal ini Pasar Hewan Wage Tulakan merupakan tempat tawar menawar barang yang berupa hewan, 
seperti sapi dan kambing. Dalam transaksi jual beli di Pasar Hewan Wage Tulakan ini terjadi komunikasi yang singkat atau menggunakan kalimat yang tidak lengkap. Hal ini disebabkan oleh situasi serta waktu yang terbatas. Apalagi Pasar Hewan Wage Tulakan merupakan pasar yang terbatas waktunya karena pasar tersebut buka mulai pukul delapan hingga satu siang. Di samping itu, Pasar Wage Tulakan hanya melakukan transaksi jual beli pada hari Wage, yakni sebutan hari dalam bahasa Jawa. Hal inilah yang menarik untuk diteliti, mengingat tuturan-tuturan singkat antara penjual dan pembeli ketika berinteraksi. Akan tetapi, tuturan-tuturan tersebut mudah dipahami karena sesuai dengan situasi dan konteks yang sedang berlangsung.

Penelitian yang terkait dengan implikatur sejauh ini belum banyak dilakukan. Di antaranya Implikatur pada Ujaran Pengguna Jasa Angkutan Umum di Kalimantan Selatan oleh Hidayatullah (2009), Pelanggaran Implikatur Percakapan dalam Humor (Tinjauan Pragmatik terhadap Humor Berbahasa Minang di Facebook) oleh Zawarnis (2013), dan Implikatur Percakapan dalam Transaksi Jual Beli di Pasar Tradisional di Kota Palu oleh Nurmiah (2014). Penelitian-penelitian tersebut mengkaji implikatur percakapan dengan fokus kajian yang berbeda-beda. Hidayatullah (2009) kajiannya fokus pada ujaran-ujaran pengguna jasa angkutan umum yang terdapat di Kalimantan Selatan. Kemudian, Zawarnis (2013) kajiannya terfokus pada pelanggaran implikatur percakapan dengan objek kajian humor berbahasa Minang di facebook. Selanjutnya, Nurmiah (2014) mengkaji implikatur percakapan dari transaksi jual beli di pasar tradisional di Kota Palu.

Sejauh ini, penelitian khusus yang membahas mengenai implikatur percakapan dalam transaksi jual beli di Pasar Hewan Wage Tulakan belum ditemukan. Padahal, kajian ini perlu dilakukan mengingat penggunaan bahasa yang singkat pada saat transaksi berlangsung. Bahkan, kalimat yang dituturkan kadang-kadang tidak lengkap serta makna yang digunakan menimbulkan ketaksaan. Dengan demikian, pentingnya kajian yang lebih mendalam mengenai implikatur percakapan antara penjual dan pembeli pada saat melakukan transaksi di pasar hewan.

Berdasarkan uraian terdahulu, pokok permasalahan dalam penelitian ini adalah bagaimanakah implikatur percakapan yang digunakan oleh penjual dan pembeli dalam transaksi jual beli di Pasar Hewan Wage Tulakan? Tujuan yang ingin dicapai dalam penelitian ini adalah untuk mendeskripsikan implikatur percakapan yang digunakan oleh penjual dan pembeli dalam transaksi jual beli di Pasar Hewan Wage Tulakan.

Hasil penelitian ini diharapkan dapat menjadi informasi yang lebih spesifik terhadap kajian implikatur percakapan dalam transaksi jual beli di Pasar Hewan Wage Tulakan. Di samping itu, hasil penelitian ini juga diharapkan dapat dijadikan bahan serta acuan bagi penelitian-penelitian lanjutan. 


\section{KERANGKA TEORI}

Implikatur berkaitan dengan kajian pragmatik karena peristiwa tutur yang wujud penggunaan bahasanya dipengaruhi oleh berbagai faktor, seperti penutur, mitra tutur, situasi dan peristiwa serta tujuan dari pertuturan tersebut. Lubis (2011: 70) menyatakan bahwa implikatur adalah arti atau aspek arti pragmatik. Dengan demikian, hanya sebagian saja dari arti literal (harfiah) itu yang turut mendukung arti sebenarnya dari sebuah kalimat, selebihnya berasal faktafakta di sekeliling kita, situasinya, dan kondisinya.

Sehubungan dengan itu, Yule (2006: 3) berpendapat bahwa pragmatik adalah studi tentang makna yang disampaikan oleh penutur (penulis) dan ditafsirkan oleh pendengar (pembaca). Pendapat yang sama juga dikemukakan Leech (2011: 19) bahwa pragmatik adalah studi mengenai makna dalam hubungannya dengan situasi ujar. Aspek situasi ujar meliputi penyapa dan pesapa, konteks sebuah tuturan, tujuan sebuah tuturan, tuturan sebagai sebuah bentuk tindakan, dan tuturan sebagai produk suatu tindak verbal.

Dengan demikian, di dalam sebuah peristiwa tutur antara penutur dan mitra tutur tentunya menggunakan percakapan ataupun tuturan-tuturan berdasarkan konteksnya. Ismari (1995: 3) mengemukakan mereka yang mengambil bagian dalam proses percakapan tersebut akan memberikan asumsi-asumsi dan harapan-harapan mengenai percakapan sehingga percakapan tersebut berkembang sesuai dengan jenis kontribusi yang diharapkan dan telah dibuat oleh mereka.

Konsep implikatur pertama kali diperkenalkan oleh Grice untuk memecahkan persoalan makna bahasa yang tidak dapat diselesaikan oleh teori semantik biasa (Rani, dkk, 2004: 170). Secara etimologis, implikatur diturunkan dari implicatum. Secara nominal, istilah ini hampir sama dengan kata implication, yang artinya maksud, pengertian, keterlibatan (Echols dalam Mulyana, 2005: 11). Brown dan Yule (1983: 11) berpendapat bahwa konsep mengenai implikatur dipakai untuk memperhitungkan hal yang disarankan atau hal yang dimaksudkan oleh penutur sebagai sesuatu yang berbeda dari yang dinyatakan secara harfiah.

Levinson (dalam Purba, 2002: 41) mengemukakan bahwa implikatur memberikan penjelasan fungsional atas fakta kebahasaan yang tidak terjangkau oleh teori linguistik. Implikatur juga memberikan penjelasan yang tegas dan eksplisit tentang bagaimana sesuatu yang diucapkan secara lahiriah berbeda dari apa yang dimaksud.

Kemudian, Grice (dalam Rahardi, 2002: 43) di dalam artikelnya yang berjudul Logic and Conversation menyatakan bahwa sebuah tuturan dapat mengimplikasikan proposisi yang bukan merupakan bagian dari 
tuturan tersebut. Proposisi yang diimplikasikan itu dapat disebut dengan implikatur percakapan. Di dalam implikatur, hubungan antara tuturan yang sesungguhnya dengan maksud yang tidak dituturkan itu bersifat tidak mutlak.

Selanjutnya, Grice (dalam Hidayatullah, 2009: 76) secara sederhana memberi pengertian bahwa implikatur adalah maksud suatu ucapan atau apa yang diimplikasikan. Ia juga memberi pengertian agak luas bahwa implikatur adalah apa yang disampaikan dan apa yang diimplikasikan, yaitu apa yang disampaikan minus apa yang diucapkan. Dengan demikian, di dalam sebuah tuturan konsep implikatur digunakan untuk membedakan hal yang dituturkan dengan hal yang dimplikasikan.

Grice (dalam Mulyana, 2005: 12) menyatakan bahwa ada dua macam implikatur, yaitu: (1) conventional implicature (implikatur

konvensional) dan conversation implicature (implikatur percakapan). Perbedaan keduanya secara tegas dijelaskan oleh Lyons (1995: 272) sebagai berikut:

"The difference between them is that the former depend on something other than what is truth-conditional in the conventional use, or meaning, of particular forms of expressions, whereas the latter derive from a set of more general principles which regulate the proper conduct of conversation".

Dengan demikian, implikatur konvensional adalah pengertian yang bersifat umum dan konvensional. Semua orang sudah mengetahui tentang maksud atau makna sesuatu hal. Di dalam implikatur konvensional, maksud atau makna terhadap sesuatu bersifat lebih tahan lama dan sudah diketahui secara umum.

Sementara itu, Levinson (dalam Mulyana, 2005: 13) menyatakan bahwa implikatur percakapan memiliki makna dan pengertian yang lebih bervariasi. Pasalnya pemahaman terhadap hal "yang dimaksudkan" sangat bergantung kepada konteks terjadinya percakapan. Implikatur percakapan hanya muncul dalam suatu tindak percakapan (speech act). Oleh karenanya, implikatur tersebut bersifat temporer (terjadi saat berlangsungnya tindak percakapan), dan nonkonvensional (sesuatu yang diimplikasikan tidak mempunyai relasi langsung dengan tuturan yang diucapkan).

Pendapat yang sama juga dikemukakan oleh Kridalaksana (2011: 91) bahwa implikatur percakapan merupakan makna yang dipahami tetapi tidak atau kurang terungkap dalam apa yang diucapkan. Kemudian, dijelaskan implikatur konvensional merupakan makna yang dipahami atau diharapkan pada bentukbentuk bahasa tertentu tetapi tidak terungkap.

Selanjutnya, Levinson (dalam Rani, dkk, 2004: 171), menyatakan bahwa ada empat macam faedah konsep implikatur, yaitu: dapat memberikan penjelasan makna atau fakta-fakta 
kebahasaan yang tidak terjangkau oleh teori-teori linguistik; dapat memberikan penjelasan yang tegas tentang perbedaan lahiriah dari yang dimaksud si pemakai bahasa; (3) dapat memberikan pemerian semantik yang sederhana tentang hubungan klausa yang dihubungkan dengan kata penghubung yang sama; (4) dapat memerikan bebagai fakta yang secara lahiriah kelihatan tidak berkaitan, malah berlawanan.

Dalam implikatur percakapan antara penjual dan pembeli ketika terjadi transaksi di Pasar Hewan Wage Tulakan, tuturan-tuturan antara penjual dan pembeli dapat dilihat dari kalimat yang digunakan. Hal ini seperti yang dikemukakan oleh Putrayasa (2010: 10) bahwa setiap gagasan, pikiran, atau konsep yang dimiliki seseorang pada praktiknya akan dituangkan ke dalam bentuk kalimat. Satu hal yang perlu dicatat ialah setiap tutur atau wicara terbentuk dari kalimat atau kalimat-kalimat. Jadi, dapatlah dikatakan bahwa sebuah tutur atau wicara terbentuk atas kalimat yang berlangsung dalam arus ujaran yang berupa bunyi. Baik bunyi maupun kalimat merupakan materi dari tutur atau wicara itu. Manusia berkalimat (Parera, 2009: 21).

Kalimat atau tuturan tersebut berbentuk kalimat perintah (imperatif), kalimat berita (deklaratif), dan kalimat tanya (interogatif). Rahardi (2002: 79) mengemukakan bahwa kalimat imperatif mengandung maksud memerintah atau meminta agar mitra tutur melakukan suatu sebagaimana diinginkan si penutur. Menurut Kridalaksana (2011: 91) imperatif merupakan bentuk kalimat atau verba untuk mengungkapkan perintah atau keharusan atau larangan melaksanakan perbuatan. Konsep gramatikal ini harus dibedakan dari perintah yang merupakan konsep semantis. Selanjutnya, Alwi (2003: 353) mengemukakan ciri kalimat imperatif adalah intonasi yang ditandai nada rendah di akhir tuturan, pemakaian partikel penegas, penghalus, kata tugas ajakan, harapan, permohonan, dan larangan.

Rahardi (2002: mengemukakan bahwa kalimat berita atau kalimat deklaratif mengandung maksud memberitakan sesuatu kepada si mitra tutur. Sesuatu yang diberitakan kepada mitra tutur itu merupakan pengungkapan suatu peristiwa atau suatu kejadian. Kalimat deklaratif dapat merupakan tuturan langsung dan dapat pula merupakan tuturan tidak langsung. Dengan demikian, kalimat berita atau kalimat deklaratif digunakan penutur kepada mitra tutur untuk menyatakan sesuatu yang isinya mengandung berita.

Selanjutnya, Rahardi (2002: 76) mengemukakan bahwa kalimat 
interogatif adalah kalimat yang mengandung maksud menanyakan sesuatu kepada si mitra tutur. Dengan perkataan lain, apabila seorang penutur bermaksud mengetahui jawaban terhadap suatu hal atau suatu keadaan, penutur akan bertutur dengan menggunakan kalimat interogatif kepada si mitra tutur.

Hal yang sama juga dikemukakan Kridalaksana (2011: 95) bahwa kalimat tanya (interogatif) merupakan bentuk verba atau tipe kalimat yang dipergunakan untuk mengungkapkan pertanyaan. Dengan demikian, kalimat tanya atau kalimat interogatif merupakan kalimat yang berfungsi untuk menanyakan sesuatu hal. Kalimat tanya ditandai dengan kehadiran kata tanya, seperti siapa, apa, di mana, berapa, kapan, dan bagaimana yang disertai atau tanpa partikel -kah sebagai penegas.

\section{METODE PENELITIAN}

Metode yang digunakan dalam penelitian ini adalah metode deskriptif dengan pendekatan kualitatif, yaitu dilakukan dengan cara mendeskripsikan bentuk-bentuk kebahasaan dalam transaksi jual beli di Pasar Hewan Wage Tulakan. Dalam penelitian ini dilakukan tiga langkah kerja, yaitu: (1) tahap penyediaan data; (2) tahap analisis data; dan (3) tahap penyajian hasil analisis data seperti yang diungkapkan Sudaryanto (2015: 6).

Sumber data dalam penelitian ini adalah bahasa lisan yang dituturkan oleh penjual dan pembeli yang sedang melakukan transaksi jual beli di Pasar Hewan Wage Tulakan. Sebelumnya, Pasar Hewan Wage Tulakan bernama Pasar Senen dan kegiatan transaksi pun dilakukan pada hari Senen dalam sebutan hari bahasa Jawa. Pasar Hewan Wage Tulakan melakukan transaksi mulai pukul delapan hingga pukul satu siang. Pasar Hewan Wage Tulakan hanya menjual hewan sapi dan kambing. Akan tetapi, yang menarik dari transaksi ini adalah dijualnya hewan dengan sistem boyongan atau borongan, yakni sapi dan kambing dapat dibeli beserta anaknya dalam satu paket. Pengambilan tuturan lisan antara penjual dan pembeli sebagai data dalam penelitian ini adalah berdasarkan asumsi bahwa tuturan yang digunakan ketika bertransaksi akan memunculkan berbagai implikatur percakapan.

Pengambilan data dalam penelitian ini dilakukan pada bulan April dan Mei 2016 di Pasar Hewan Wage Tulakan, Desa Tulakan Kecamatan Tulakan Kabupaten Pacitan Jawa Timur. Dalam penyediaan data digunakan (1) metode simak, baik simak libat cakap atau simak bebas libat cakap dan (2) teknik catat (Mahsun, 2013: 93).

Dalam metode simak dilakukan dengan cara menyimak tuturan penjual dan pembeli. Kemudian, teknik catat merupakan teknik lanjutan yang dilakukan dengan mencatat data, berupa tuturantuturan penjual dan pembeli. Pada 
tahap analisis data, tuturan antara penjual dan pembeli diklasifikasikan berdasarkan penggunaan implikatur percakapan. Sehubungan dengan tahap analisis data Sudaryanto (dalam Nurmiah, 2014: 200) menyatakan bahwa hasil analisis data dapat disajikan dengan menggunakan dua metode, yaitu metode informal dan metode formal. Dalam penelitian ini, hasil analisis data yang digunakan untuk memaparkan implikatur percakapan antara penjual dan pembeli ialah metode informal, yaitu dengan penyajian berbentuk uraian kalimat.

\section{ANALISIS DAN PEMBAHASAN}

Berdasarkan data yang diperoleh, dapat dideskripsikan wujud implikatur percakapan antara penjual (Pj) dan pembeli $(\mathrm{Pb})$ yang sedang melakukan transaksi di Pasar Hewan Wage Tulakan. Berikut hasil analisis data penggunaan implikatur percakapan dalam transaksi jual beli di Pasar Hewan Wage Tulakan.

\section{Implikatur dalam Kalimat Perintah}

Ketika terjadi transaksi antara penjual dan pembeli di Pasar Hewan Wage Tulakan, terlihat jelas bahwa pembeli yang ingin membeli hewan, baik sapi ataupun kambing menggunakan implikatur percakapan dalam kalimat perintah. Berikut data yang menunjukkan penggunaan implikatur percakapan dalam kalimat perintah.

\section{Peristiwa Tutur 1}

$\mathrm{Pb}$ : Pinten regane mendho niku Mbah? Berapa harga kambingnya Mbah?

Pj: Sing endi Pak?

Yang mana Pak?

$\mathrm{Pb}$ : Ingkang jaler niku!

Kambing ini jantan!

Pj: Sak juto limangatus ewu, Pak.

Satu juta lima ratus ribu, Pak.

$\mathrm{Pb}$ : Setunggal yuto tigang atus nggeh

Satu juta tiga ratus ya.

Pj: Gak entuk Pak lek sing iku! Lek sing iki entak masalahe weduse rodok cilik

$\mathrm{Pb}$ : Boten angsal kurang maleh nggeh Mbah?

Tidak kurang lagi ya Mbah?

Pj: Ora entuk Pak.

Tidak bisa lagi.

$\mathrm{Pb}$ : Udari jirete, Mbah!

Lepaskan pengikatnya, Mbah!

Peristiwa tutur (1) di atas terjadi di tempat penjual kambing. Implikatur yang terjadi dapat dilihat pada kalimat yang diucapkan oleh pembeli, yaitu Udari jirete, Mbah!. Tuturan yang diucapkan oleh pembeli tersebut mengimplikasikan bahwa si pembeli ingin membeli kambing. Akan tetapi, pembeli, tidak langsung berkata "Saya jadi membeli kambing". Si pembeli berkata dengan mengimplikasikannya dengan tuturan Udari jirete, Mbah!. Secara tidak langsung maksud tuturan Udari jirete, Mbah! adalah si pembeli menyuruh penjual melepaskan pengikat tali kambing. Meskipun, pembeli menggunakan tuturan yang tidak lengkap, tetapi penjual dapat memahami maksud 
dari pembeli. Hal ini disebabkan, baik penjual maupun pembeli telah memahami konteks dan situasi yang sedang berlangsung sehingga pembeli tidak perlu lagi menggunakan tuturan yang lengkap untuk mengatakan keinginannya.

\section{Peristiwa Tutur 2}

$\mathrm{Pb}$ : Pinten mendho ingkang alit niku, $\mathrm{Bu}$ ?

Berapa Kambing yang kecil, $\mathrm{Bu}$ ?

Pj: Nematus ewu, Dek.

Enam ratus ribu, Dik.

$\mathrm{Pb}$ : Ingkang diiket niku pinten $\mathrm{Bu}$ ?

Yang diikat sana berapa $\mathrm{Bu}$ ?

Pj: Iku limangatus ewu.

Itu lima ratus ribu.

$\mathrm{Pb}$ : Ingkang gangsallatus ewu mawon Bu.

Yang lima ratus ribu saja Bu!

Peristiwa tutur (2) di atas terjadi di tempat penjual kambing. Implikatur terjadi dalam tuturan pembeli, yaitu Ingkang gangsallatus ewu mawon Bu. Tuturan Ingkang gangsallatus ewu mawon Bu mengimplikasikan bahwa si pembeli ingin membeli kambing yang harganya lima ratus ribu saja. Akan tetapi, si pembeli tidak menggunakan tuturan yang lengkap "Saya ingin membeli kambing yang harganya lima ratus ribu saja". Si pembeli hanya menggunakan kalimat perintah Ingkang gangsallatus ewu mawon Bu. Kalimat yang diucapkan pembeli pun sudah dipahami penjual.

\section{Peristiwa Tutur 3}

$\mathrm{Pb}$ : Lembu ingkang niku meteng nggeh Pak?
Sapi ini hamil ya Pak?

Pj: Iyo.

Iya.

$\mathrm{Pb}$ : Pinten reginipun Pak?

Berapa harganya Pak?

Pj: Regane pitulas yuto Dek.

Harganya tujuh belas juta Dik.

$\mathrm{Pb}$ : Boten angsal kurang Pak regane?

Tidak bisa kurang Pak harganya?

Pj: Ora iso Dek iku wes murah banget.

Tidak bisa lagi, sudah murah sekali.

$\mathrm{Pb}$ : Niki yotrone Pak, mang sampeyan itung disik!

Ini uangnya Pak, dihitung dulu!

Pada data (3) di atas, implikatur percakapan dapat dilihat pada tuturan yang diucapkan oleh pembeli, yaitu Niki yotrone Pak, mang sampeyan itung disik. Tuturan tersebut mengimplikasikan bahwa si pembeli ingin membeli sapi. Akan tetapi, pembeli tidak langsung menggunakan tuturan "Saya ingin membeli sapi". Pembeli hanya mengimplikasikannya dengan tuturan Niki yotrone Pak, mang sampeyan itung disik. Dengan kalimat perintah yang dituturkan pembeli dimaksudkan bahwa si pembeli menyuruh penjual untuk melakukan sesuatu, yaitu menghitung uang yang diberikan pembeli untuk membeli sapi.

\section{Implikatur dalam Kalimat Berita}

Dalam transaksi jual beli di Pasar Hewan Wage Tulakan juga ditemukan implikatur percakapan dalam kalimat berita yang digunakan antara penjual dan pembeli. Berikut data yang 
menunjukkan implikatur percakapan dalam kalimat berita.

\section{Peristiwa Tutur 4}

$\mathrm{Pb}$ : Lembunya sing niki pinten Mbah?

Sapinya yang ini berapa Mbah?

Pj: Sing niki sewelas juta.

Yang ini sebelas juta.

$\mathrm{Pb}$ : Sewelas juta niki mboten kurang Mbah?

Sebelas juta ini tidak kurang Mbah?

Pj: Sak niki regane lagi munggah Dek.

Sekarang harga sapi lagi naik Dik.

Pada peristiwa tutur (4) tampak terjadi di tempat penjual sapi. Implikatur dapat dilihat pada tuturan yang disampaikan oleh penjual. Tuturan yang disampaikan oleh penjual merupakan kalimat berita, yaitu Sak niki regane lagi munggah Dek yang maksudnya menyatakan bahwa sekarang harga sapi sedang naik dari harga biasanya. Si penjual tidak menggunakan tuturan "tidak bisa kurang" untuk menjawab pertanyaan dari pembeli. Akan tetapi, menggunakan tuturan Sak niki regane lagi munggah Dek. Si pembeli pun sudah mengerti maksud dari ujaran yang disampaikan penjual. Dengan demikian, implikatur yang terkandung dalam tuturan Sak niki regane lagi munggah Dek untuk menginformasikan sesuatu.

\section{Peristiwa Tutur 5}

$\mathrm{Pb}$ : Sapi iku piro regane Mas?

Sapi ini berapa Mas?

Pj: Sing wedok iku sewelas juta.
Yang ini sapi betina sebelas juta.

$\mathrm{Pb}$ : Lek sing anak'e iku piro?

Kalau anaknya ini?

Pj: Telung yuto.

Tiga juta.

$\mathrm{Pb}$ : Gak iso kurang meneh to Mas?

Tidak kurang lagi Mas?

Pj: Wis lek ngono ngene ae tuku sak boyongan babone karo anak'e telulas yuto.

Kalau begitu beli yang borongan saja harga sapi betina dan anaknya tiga belas juta.

Pada peristiwa tutur (5) di atas terjadi di tempat penjual sapi. Implikatur yang terjadi dapat dilihat bahwa tuturan Wis lek ngono ngene ae tuku sak boyongan babone karo anak'e telulas yuto yang diucapkan penjual mengimplikasikan bahwa harga sapi betina dan anak sapi yang dijualnya tidak bisa ditawar lagi. Untuk mengimplikasikannya, si penjual menggunakan tuturan Wis lek ngono ngene ae tuku sak boyongan babone karo anak'e telulas yuto. Si pembeli pun sudah memahami maksud dari penjual. Dengan demikian, implikatur yang terkandung dalam tuturan Wis lek ngono ngene ae tuku sak boyongan babone karo anak' telulas yuto adalah memberitahukan sesuatu, yaitu lebih murah membeli sapi dengan borongan sapi betina dan anak sapi daripada membelinya secara terpisah.

\section{Peristiwa Tutur 6}

Pj: Wedus wedok Pak? Mirah

Kambing betina Pak? Murah

$\mathrm{Pb}$ : Pinten regane Mbah?

Berapa harganya Mbah? 
Pj: Sak yuto satus

Satu juta seratus

$\mathrm{Pb}$ : Boten setunggal yuto mawon

Mbah?

Tidak satu juta saja Mbah.

Pj: Waduh wes murah iku Pak!

Waduh, sudah murah Pak!

Pada data (6) di atas terlihat implikatur terjadi di tempat penjual kambing. Tuturan yang diucapkan penjual, yaitu Waduh wes murah iku Pak! mengimplikasikan bahwa kambing yang ditawar pembeli harganya tidak bisa kurang lagi. Untuk mengimplikasikan harga yang ditawar pembeli tersebut, si penjual tidak menggunakan tuturan "tidak bisa ditawar lagi". Akan tetapi, penjual menggunakan tuturan Waduh wes murah iku Pak!. Dengan tuturan yang diucapkan oleh penjual, si pembeli mengerti sehingga tidak menawar lagi. Dengan demikian, maksud yang terkandung dalam implikatur tersebut adalah untuk menginformasikan sesuatu, yaitu harga yang tidak bisa ditawar lagi.

\section{Implikatur dalam Kalimat Tanya}

Ketika penjual dan pembeli melakukan transaksi di Pasar Hewan Wage, selain implikatur percakapan dalam kalimat perintah dan kalimat berita, ditemukan juga penggunaan implikatur percakapan dalam kalimat tanya. Implikatur percakapan dalam kalimat tanya dapat dilihat pada data berikut.

\section{Peristiwa Tutur 7}

$\mathrm{Pb}$ : Wedus sing cilik iku piro Mbak?
Kambing kecil ini berapa Mbak?

Pj: Nem atus ewu Bu.

Enam ratus ribu, $\mathrm{Bu}$.

$\mathrm{Pb}$ : Iku limangatus ewu.

Ini lima ratus ribu.

Peristiwa tutur (7) di atas terjadi di tempat penjual kambing. Implikatur terlihat pada tuturan yang diucapkan oleh pembeli, yaitu Iku limangatus ewu. Tuturan tersebut mengimplikasikan bahwa si pembeli menawar harga kambing. Si pembeli tidak menggunakan kalimat tanya "Bisakah harga kambingnya lima ratus ribu?", tetapi mengimplikasikannya dengan tuturan Iku limangatus ewu. Dengan tuturan yang diucapkan si pembeli, penjual sudah memahami maksud pembeli, yaitu menawar harga kambing yang dijualnya seharga lima ratus ribu. Jadi, implikatur yang terkandung dalam tuturan tersebut adalah si pembeli bertanya.

\section{Peristiwa Tutur 8}

$\mathrm{Pb}$ : Wedus lanang iku piro regane Dek. Kambing jantan ini berapa Dik.

Pj: Sak yuto pitung atus ewu Pak. Satu juta tujuh ratus Pak

$\mathrm{Pb}$ : Sak yuto limangatus ewu ae yo. Wah ini, satu juta lima ratus ribu.

Pada data (8) di atas terjadi di tempat penjual kambing. Implikatur terjadi dari tuturan yang diucapkan pembeli, yaitu Sak yuto limangatus ewu ae yo. Tuturan tersebut mengimplikasikan bahwa si pembeli menawar harga kambing jantan. Untuk mengimplikasikannya, si 
pembeli menggunakan tuturan Sak yuto limangatus ewu ae yo. Pembeli tidak langsung bertanya "Bisakah harganya kambing jantan ini satu juta lima ratus ribu?". Akan tetapi, pembeli mengimplikasikannya dengan tuturan Sak yuto limangatus ewu ae yo. Dengan tuturan tersebut, penjual sudah memahami arah pembicaraan pembeli. Jadi, implikatur yang terkandung dalam tuturan tersebut adalah si pembeli secara tidak langsung bertanya kepada penjual.

\section{Peristiwa Tutur 9}

Pb: Piro iku Pak?

Berapa ini Pak?

Pj: Lembune niki meteng lan lemu Mbah pitulas yuto.

Sapi ini hamil dan gemuk Mbah, tujuh belas juta.

$\mathrm{Pb}$ : Biasane iku nembelas yuto.

Biasanya ini enam belas juta.

Peristiwa tutur (9) di atas terjadi di tempat penjual sapi. Implikatur dapat dilihat pada tuturan yang diucapkan oleh pembeli, yaitu Biasane iku nembelas yuto. Tuturan tersebut mengimplikasikan bahwa si pembeli menawar harga sapi enam belas juta, tetapi pembeli tidak menggunakan tuturan "Bisakah harga sapinya enam belas juta?". Meskipun begitu, penjual memahami maksud tuturan pembeli yang menawar harga sapi yang dijualnya. Dengan demikian, implikatur yang terkandung pada tuturan Biasane iku nembelas yuto, yaitu si pembeli bermaksud bertanya.

\section{PENUTUP}

\section{Simpulan}

Berdasarkan hasil pembahasan implikatur percakapan dalam transaksi jual beli di Pasar Hewan Wage Tulakan dapat disimpulkan bahwa interaksi yang terjadi antara penjual dan pembeli menggunakan tuturan-tuturan singkat atau menggunakan kalimat yang tidak lengkap. Hal ini disebabkan oleh situasi serta waktu yang terbatas. Akan tetapi, tuturan-tuturan tersebut mudah dipahami karena sesuai dengan situasi dan konteks yang sedang berlangsung. Bentuk implikatur percakapan yang digunakan, yaitu: (1) implikatur percakapan terungkap dalam kalimat perintah, (2) implikatur percakapan terungkap dalam kalimat berita, dan (3) implikatur percakapan terungkap dalam kalimat tanya.

\section{Saran}

Berdasarkan hasil penelitian disarankan, penelitian ini dapat dijadikan bahan acuan bagi penelitian lanjutan untuk mengkaji tentang implikatur percakapan. Di samping itu, masih banyak aspek pragmatik yang perlu dikaji lagi dalam transaksi jual beli di Pasar Hewan Wage Tulakan. 
Undas Vol 12. , Nomor 2, Desember $2016: 11--24$

\section{DAFTAR PUSTAKA}

Alwasilah, A. Chaedar. 2010. Filsafat Bahasa dan Pendidikan. Bandung: Remaja Rosdakarya.

Alwi, Hasan, dkk. 2003. Tata Bahasa Baku Bahasa Indonesia. Jakarta: Balai Pustaka.

Brown, Gillian dan George Yule. 1983. Discourse Analysis. Cambridge: Cambridge University Press.

Hidayatullah, Dede. 2009. "Implikatur pada Ujaran Pengguna Jasa Angkutan Umum di Kalimantan Selatan". Dalam UNDAS Jurnal Hasil Penelitian Bahasa dan Sastra V (1): 7486. Balai Bahasa Banjarmasin.

Ismari. 1995. Tentang Percakapan. Surabaya: Airlangga University Press.

Jahdiah. 2013. “Prinsip Kerja Sama dalam Transaksi Jual Beli di Pasar Martapura”. Dalam Bunga Rampai Kebahasaan, hlm. 25-45. Banjarbaru: Balai Bahasa Provinsi Kalimantan Selatan.

Kridalaksana, Harimurti. 2011. Kamus Linguistik. Jakarta: Gramedia Pustaka Utama.

Lubis, A. Hamid Hasan. 2011. Analisis Wacana Pragmatik. Bandung: Angkasa.

Leech, Geoffrey. 2011. Prinsip-Prinsip Pragmatik. Penerjemah Oka, M.D.D. Jakarta: Universitas Indonesia Press.

Lyons, John. 1995. Linguistics Semantics. Cambridge: CU Press.

Mahsun, M.S. 2013. Metode Penelitian Bahasa: Tahapan Strategi, Metode, dan Tekniknya. Jakarta: RajaGrafindo Persada.

Mulyana. 2005. Kajian Wacana Teori, Metode dan Aplikasi Prinsip-Prinsip Analisis Wacana. Yogyakarta: Tiara Wacana.

Muslich, Masnur dan I Gusti Ngurah Oka. 2010. Perencanaan Bahasa pada Era Globalisasi. Jakarta: Bumi Aksara.

Nurmiah. 2014. "Implikatur Percakapan dalam Transaksi Jual Beli di Pasar Tradisional di Kota Palu". Dalam Multilingual Jurnal Kebahasaan dan Kesastraan XIII (2): 196-207. Balai Bahasa Provinsi Sulawesi Tengah.

Parera, J. D. 2009. Dasar-Dasar Analisis Sintaksis. Jakarta: Erlangga.

Pranowo. 2012. Berbahasa secara Santun. Yogyakarta: Pustaka Pelajar.

Purba, Antila. 2002. Pragmatik Bahasa Indonesia. Medan: Universitas Sumatera Utara.

Putrayasa, Ida Bagus. 2010. Kalimat Efektif (Diksi, Struktur, dan Logika). Bandung: Refika Aditama. 
Implikatur Percakapan dalam Transaksi Jual Beli di Pasar Hewan Wage Tulakan (Hestiyana)

Rahardi, Kunjana. 2002. Pragmatik Kesantunan Imperatif Bahasa Indonesia. Jakarta: Erlangga.

Rani, Abdul, dkk. 2004. Analisis Wacana: Sebuah Kajian Bahasa dalam Pemakaian. Malang: Banyu Media.

Sudaryanto. 2015. Metode dan Aneka Teknik Analisis Bahasa Pengantar Penelitian Wahana Kebudayaan secara Linguistis. Yogyakarta: Sanata Dharma University Press.

Swastha, Basu. 1996. Azas-Azas Marketing. Yogyakarta: Liberti Yogyakarta.

Wijana, I Dewa Putu. 1996. Dasar-Dasar Pragmatik. Yogyakarta: Andi Offset.

Yule, Geoge. 2006. Pragmatik. Penerjemah Indah Fajar Wahyuni. Yogyakarta: Pustaka Pelajar.

Zawarnis, Yulfi. 2013. “Pelanggaran Implikatur Percakapan dalam Humor (Tinjauan Pragmatik terhadap Humor Berbahasa Minang di Facebook)". Dalam Kelasa Jurnal Kelebat Masalah Bahasa dan Sastra VIII (1): 49-64. Balai Bahasa Provinsi Lampung. 